\title{
K.H. AHMAD DAHLAN'S (1869 - 1923) THOUGHT AND HIS STRUGGLE FOR THE ABOLITION OF FEUDALISM THROUGH REFORMATION OF ISLAMIC EDUCATION
}

\author{
Suswandari \& Suwarno ${ }^{1}$
}

\begin{abstract}
This article examines the founder of the Muhammadiyah, K. H. Ahmad Dahlan (1869-1923) and the reformation of Islamic education he had proclaimed as an attempt to abolish all feudalism force in society towards a realistic and democratic modern society. The clerical reformist, $K$. H. Ahmad Dahlan played an essential role and was the key for the improvement and the reawakening of Muslim society so as to abandon the rooted feudal cultural practice. This article first discuss the childhood of K. $H$. Ahmad Dahlan and his education. The article then discusses the socio-cultural context of feudalist Muslim society within his neighborhood. Then, the article also discusses the Islamic education reformation proclaimed by K. H. Ahmad Dahlan referring to his notion on Islamic education reformation, his view on the relation between religion and mind, as well as his political view.
\end{abstract}

Key words: feudalism, Ahmad Dahlan, Muhammadiyah, and reformation of Islamic education

\section{Introduction}

This paper was written as to celebrate the milad (birth day) of Muhammadiyah that has been exist for a century as well as to commemorate the $46^{\text {th }}$ Muktamar Muhammadiyah hold in Yogyakarta on 3-8 July 2010 M. The founder of Muhammadiyah has been acknowledged as national hero, and it is necessary that reader will get a moral lesson or al 'ibrah from the thought of the figure.

K. H. Ahmad Dahlan (1869 - 1923) is a prominent figure known as the founder of Muhammadiyah established on 18 November 1912 or 8 Dzulhijah 1330 $\mathrm{H}$. As has been known, Muhammadiyah is an organization of modern Islamic reform that still exists until this day and known as the second largest Islamic organization in Indonesia after Nahdlatul Ulama (NU) that was found in 1926. While Muhammadiyah represents the modernists lived in cities; NU, however,

${ }^{1}$ Dr. Suswandari. Chief Lector. Lecturer of Study Program of History Education of FKIP and Post Graduate Study of Universitas Muhammadyiah Prof Dr. Hamka (UHAMKA). Jakarta ${ }^{\$ \S}$ Suwarno., Lecturer of Study Program of History Education of FKIP Universitas Muhammadiyah Purwokerto. Their article has been reviewed by Prof. Dr. Said Hamid Hasan, MA (Universitas Pendidikan Indonesia), and Dr. Abdul Razaq Ahmad (Univerisiti Kebangsaan Malaysia) 
represents Pesantren-based traditionalists who lived in villages. Muhammadiyah has shown a good improvement in terms of zonal range, membership and supporterhood, as well as in the terms of field work, especially for education as well as social and medical service.However, K. H. Ahmad Dahlan is not the first Islamic reformist in Indonesian archipelago.

Before him, there was Syaikh Ahmad Khatib (born in Bukittinggi West Sumatera, in 1855), a well known ulama who spread his thought he got from Makkah within twelve decades before the $20^{\text {th }}$ century. He was an imam of Masjid al - Haram Makkah who followed Mazhab Syafii and became the teacher for reformists such as Syaikh Muhammad Djamil Djambek (born in 1860), Haji Abdul Karim Amrullah (Hamka's father, born in 1879), and Haji Abdullah Ahmad (born in 1878), where the three of them conducted their activities around Minangkabau (Noer, 1990: 39). those Islamic reformists, including K. H. Ahmad Dahlan, can be considered as the key for the improvement and the redevelopment of Muslim society.

In Java, there were some prominent figures that lived in the same age as K. H. Ahmad Dahlan and contributed to the Islamic reformation. Among them were Syaikh Ahmad Soorkati (born in 1872, in Sudan), who came to Indonesia in 1911 and supported the awakening of Al-Irsyad founded in 1914. The other was ustadz A. Hassan (born in 1887, in Singapore), who came to Indonesia in 1921 and actively involved in Islamic reformation of Persatuan Islam (Persis) which was founded in 1923 by Zamzam and Muhammad Yunus (Mughni: 53, 54).

Education was the main medium for the Islamic reformists, especially for K.H. Ahmad Dahlan, as they believed that the most appropriate medium for Islamic reformation was education. In this term, education plays a role as an agent of change. The term of change here means the change of mental of Muslim society from feudal culture that was identical with people classification based on biological background, a poor, underdeveloped culture with absolute obedience.

\section{K. H. Ahmad Dahlan's Childhoold and Education}

K. H. Ahmad Dahlan (herein after Kyai Dahlan) was born in Yogyakarta in 1869. During his childhood, he was named Muhammad Darwis. He was the son of Kyai Haji Abubakar ibn Kyai Sulaiman, the khatib of Masjid Sultan of the city. Khatib is the position for clerical abdi dalem who was responsible for Friday pray at Masjid Agung Kesultanan Yogyakarta. Dahlan' mother was Haji Ibrahim's daughter (Noer, 1990: 85; Peacock, 1983: 13)

From the explanation on his family background above, it is abvious that in feudal Javanese structure, Kyai Dahlan belonged to clerical noble class. He was financially secured. Supported by the harmonious and democratic family atmosphere, he became a critical and emphatic person towards his social milieu as he matured. 
Formally, within his childhood, Kyai Dahlan did not gain education from established educational system as school. His basic literary skill was inherited from his father, his friends and brothers-in-law. In the age of eight, he was able to read and finished reading the al Qur'an. Other knowledge was gained in autodidact manner as he had a gifted bright brain (Asrofie, 2005: 33, Mulkhan, 1990: 6). Within his childhood, he also shown his leadership. Among his friends, he was likeable and followed (dululuti). By and large, he was diligent, honest and helpful. He was also good at making craft and fond of toys. His favorite ones were kite and gasing (Asrofie, 2005: 33).

However, as he went through his adolescent, Kyai Dahlan intensively learned Islamic knowledge such as nahwu, fiqh, and tafsir (interpretation) of Al Quran to clerics in his hometown. Abdul Munir Mulkhan (1990:6) shows lists of some Ulamas who became his teachers, such as Kyai Haji Muhammad Shaleh (fiqh), Kyai Haji Muhsin (nahwu), Kyai Haji Raden Dahlan (falq), Kyai Mahfudz and Syaikh Khayyat (hadits), Syaikh Amin and Sayyid Bahri Satock (qiraatul quran), Syaikh Hasan (medical). Some academicians who had influences on his knowledge were R. Ng. Sosro Soegondo and R. Wedana Dwijoseoyo. The fact that he had broad knowledge made him a wise, thoughtful and visionary person.

In 1890, Kyai Dahlan went to Makkah. When he fulfilled the fifth Rukun of the Pillars of Islam, he spent the time to learn Islam for about eight months from Ulamas such as Sayyid Bakir Syantha, imam of mazhab Syafi'i at Masjid Al Haram, Syaikh Ahmad Khatib and Kyai Nawawi of Banten. In this time his change his name to K. H. Ahmad Dahlan (Syuja', 2009: 13). Later, in 1930, at the age of 35, Kyai Dahlan went hajj with his 13 years old son, Siraj Dahlan. At the moment, Dahlan stayed there for a year and a half to learn fiqh and hadits (Asrofie, 2005: 34 - 37; bdk Mulkhan, 1990: 7).

There was no agreement among experts whether Kyai Dahlan had the notion of reformation right after the first or the second hajj. Noer (1990: 85) ensures that Kyai Dahlan had known the notion after the first hajj. M Djindar Tamimy (in Tim Pembina Al Islam dan Kemuhammadiyahan, 1990: 5), however, refers to the second hajj. Nonetheless, it is believed that while he was staying in Makah, Kyai Dahlan read and studied stories about the Reformist Clerics such as Ibn Taymiyah, Ibnul Qayyim, Muhammad ibn Abdul Wahhab, Jamaluddin al - Afghani, Muhammad Abduh and Rasyid Ridha (see Asrofie, 2005: 38 for the books read by K. H Ahmad Dahlan).

His strong commitment to science, was reflected in an event occured in 1892. At that time, there was a man who gave him 500 guldens for trading. Instead of using the money for trading, he used it for buying books (Mulkhan, 1990: 7).

\section{Socio Cultural Context of Feudal Muslim Society within His Milieu}

The national history notes that Java was once in the era of feudalism. On this regard, Burger says that as the sea trade seemed to disappear, social structure 
of the Javanese inclined to feudal, and the existing feudalism grew stronger (Atmosudirdjo, 1970: 86). Since then, the social classes in Java consisted of two stratas, namely kings and noblemen and the lower ones included tenants. Feudalism is derived from the latin word of feudum that refers to the land owned by a knight for his payment as he had supported the authority for forty days or more. The context of feudalism grew stronger within the Javanese beaurocracy at the time, in which the whole land was owned by the authority. A number of farmers were only allowed to work on the land and were burdened with some feudalistic demands from the authority. In general, Javanese at that time was under feudalism and this was indicated by 1) social strata comprising landlord and labor 2) absolute control of higher class to the lower one, 3) absolute obedience from the lower class to the higher one, 4) a condition where the lower class' fortune was decided by the higher. 5) a condition where the authority was fully owned by the higher level society, 6) a condition where the lower had not had right to speak. Therefore, it can be concluded that feudalism is a social and political system that gives a vast authority to noblemen. This condition grew during Kyai Dahlan's childhood where he was classified as the noble.

Accordingly, the Muslim political power declined, as the dutch colonial power strongly strong influenced in the $19^{\text {th }}$ century. As noted by Noer (1990: 1121), the declining of political power did effect Muslim clerical life are indicated by: the spread of taqlid (to blindly follow fatwia and religious deed without knowing the truth of dalils or laws); the stagnation of ijtihad (a careful reasoning as to find tafsir and thought on an issue); the tendency of traditional Islamic teaching that focused on fiqh and full of tasawuf and myths; the syncretism where bid'ah, takhayul or superstitious and khurafat were fused into the practied of Islam; and an excessive respect given to Kyai.

The tendency to tasawuf and mysticism was reflected in the growth of tarekat. The term tarekat is derived from the term thariqah which refers to a way and disciplinary system to get closer to the God. The popular tarekat sects within Indonesian Muslim at that time were Naqsyabandiyah, Qadariyah and Syattariyah. Most of Muslim intellectuals state that tarekat is the main cause of the stagnation of Muslim society because it gave an over concern on spiritual ukhrawi. Nonetheless, Martin van Brinessen see a positive thing from tarekat in terms of their struggle in facing colonial. According to him, all of the tarekat sects spread in Indonesia (whether Naqsyabandiya, Qadariyah, or Syatariyah) were all dangerous for colonial power since tareqat had a role as a media to accommodate aspiration in politics and economics. These tarekat sects, however, were not antycolonisation in nature, but many people who were disappointed with the Dutch used tarekat doctrine to fight againt Dutch colonialis (Bruinessen, 1992: 30).

In this period of time, religious acts were full of bid'ah, takhayul and khurafat as reflected from the syncretism of Islamic stained with animism and dynamism which was still held by some Muslims in feudal era. Animism is a belief that the spirits of ancestors were powerful to protect villages or communities, 
could give rahmat or fortune as well as bad luck, health or disease, etc; while dynamism is a belief on invisible spirit within things such as rock, tree, keris, azimuth, and so on.

Kampung Kauman, around Kraton Sultan, where Dahlan lived, was known as the village of santri or clerical students. James L. Peacock, citing Pijper's statement in Fragmenta Islamica, explains that Kampung Kauman was a dense but rich neighborhood since most of its residence were batik merchants. The village was given a special right by Sultan to be the residential area for santri (Muslim Jawa or Javanese Muslim) and where Chinese and Christian were forbidden to live there. Islamic atmosphere was reflected in their everyday life in the village. In the afternoon, for instance, the chant of wahyu Ilahi or God's revelation was heard from all around the area and within Ramadhan, there was no one who dared to eat and drink during the day in the village (peacock, 1983: 12).

A historian from UGM, Koentowidjojo (in Rais, 1985:35-39), appropriately depicts this religious atmosphere from Javanese before the establishment of Muhamadiyah by Kyai Dahlan. According to Koentowijoyo's analysis, at that time, Javanese religious acts were colored by syncretic acts and traditional Islam. The syncretic one was represented by Javanese culture, which was centralized in Keraton, and was indicated by the feudalism (two main Keratons or palaces: Kesultanan Ngayogyakarta Hadiningrat and Kasunanan Surakarta); while the traditional one was indicated by the Kyais and their students within the villages. Syncretic Islam caused the behaviour of syirik (to believe in more than one God) such as illogical takhayul or superstitious. Meanwhile, the traditional Islam caused bid'ah and khurafat, as of manmade religious rules. Either syirik (takhayul) or bid'ah and khurafat was the concern of Kyai Dahlan's reformation along with the establishment of Muhammadiyah.

Furthermore, Koentowidjojo (Republika, 21 October 1994: 6) explains that there are at least three reasons why K. H. Ahmad Dahlan, who had conducted ijtihad as his defiance towards feudalism referring to accurate reasoning towards man problem, should be considered as a reformist. First, he gave valued a kyai as a teacher. Second, he started a new tradition from spoken to written tradition. Third, he emphasized the importance of women in religion. Koentowidjojo offers a paradigm of socio-cultural change pertaining to the role of ulama as follows :

\begin{tabular}{l|l|l|l|l}
\hline Society & Ulama & Communication & Role & Recruitment \\
\hline Pre-industrial & Kyai & Spoken & Social & Genealogy \\
Semi industrial & Teacher & Written & Politic & Politic \\
Industrial & Partner & Electronic & Electronic & Sporadic \\
\hline
\end{tabular}

From the above scheme, it can be explained that before the establishment of Muhammadiyah, Indonesian Muslim was in the preindustrial phase (before the industrial phase), ulamas were also kyai, where they disseminated their view or did the communication through spoken media, they only played a role in the 
social field, and the recruitment pattern to be a Kyai was genealogical (inherited). However, since Kyai Dahlan asserted his reformation idea, there was a change, the citizens started a semi industrial phase, ulamas became teachers, the communication was then conducted trough written media (Kyai Dahlan started it by translating Al Quran into Javanesse language through Swara Muhammadiyah magazine which was first issued in 1915), their roles had change into political ones and the recruitment pattern was segmental (more to citizen). The industrial period stated in the 1980 os by the appearance of new ulamas such as Zainuddin MZ, Rhoma Irama, Dedi Mizwar etc. that reflects the role of an ulama as partner, citizen, where communication was conducted through electronic (television, radio, etc), ulamas' roles were more to intellectual and the recruitment was more to sporadic (everyone may become an ulama). The other aspects of Kyai Dahlan concerned was the role of women in religion, as a big breakthrough in feudal culture, considering that women in feudal was only considered as "konco wingking”, the abandoned class. The appearance of Nyai Dahlan as Kyai Dahlan's wife through majelis pengajian or Quran study group of Sopo Tresno had made a big note on history of women movement that afterward they had their own mass organization named Aisiyah (Heri Sucipto and Nadjamudin Ramli, 2005: 44, see also Soeratno, 2009).

\section{Reformation of Islamic Education as the Attempt to Break the Feudalism Rigidity}

According to Deliar Noer, Kyai Dahlan had comprehended his thought and the notion of reformation as he came from his first hajj. His thought and notion were then realized, first by his effort to change the shalat direction to the appropriate Qiblah. That was not an easy thing since Kyai Dahlan should face the local authorities who hold their rooted tradition. Besides, at the same time, Kyai Dahlan started to organize his friends in Kauman to improve sanitation around the place by voluntarily worked for fixing and cleaning gutter and roads (Noer, 1990: 85).

His first reformation step in changing the direction of shalat to the real qiblah in Masjid Sultan Yogyakarta could not be realized. Even, his effort to build langgar (surau or mushala or small mosque) with the right Qiblah had a great threat from Muslim leader Kyai Haji Mohammad Halil who commanded to damage the langgar. Kyai Dahlan, at that time, almost gave up and wanted to leave his home town. Fortunately, he had a family who could guarantee that he could teach and practice his belief by building him a new langgar (Peacock, 1983: 25; Noer, 1990:85). Regarding the damages of langgar by Kyai Mohammad Halil was probably caused by two reasons, namely : 1) jealousy and 2) his traditional belief that within an area, there should only be a mosque where people can conduct Friday pray (Noer, 1990: 86). This incident reflects feudalism of being afraid of losing authority, which was often clashed with reformation. The chance to realize 
his reformation idea, then, opened to Kyai Dahlan, as he had been appointed as khatib or preacher in Masjid Sultan replacing his father. His honesty and sincerity in work made another Kyai at that time acknowledged him as ulama. It was proven by the name he got, "ketib amin" (the trusted khatib).

His vast social connection, as of becoming a member of Budi Utomo in 1909 in order to give religious lesson to the members, opened his knowledge more on the importance of reformation on Islamic education. His membership in Budi Utomo was useful to him, as a preparation on establishing an organization in order to realize his notion on the reformation. Formalization of his notion was then achieved in 1912, at 18 November (or 8 Dzulhijah 1330 h), when Kyai Dahlan succeeded to establish Muhammadiyah. The vision of the organization was to improve the religion based education, to improve the comprehension on religion, and to make people live under the rule of religion (religion here means Islam, of course) (see Pringgodigdo, 1986: 18; Nakamura, 1983: 28 - 29; and Noer, 1990: 86). Until the end of his life in 1923, Kyai Dahlan gave all efforts and concerns on the development of Muhammadiyah he established.

Regarding his reasons in establishing Muhammadiyah, A. Syafi'I Ma'arif, citing Hamka, states that it was caused by three factors, namely: 1) phenomena on the backwardness and the intellectuality of Indonesian Muslim in almost every aspects of life 2) bad poverty suffered by Muslim within this rich country, and 3) the condition of Islamic education which has been too out of date such as those practiced in pesantren (Ma'arif, 1987: 66). On the other hand, M. Djindar Tamimy (Tim Pembina al Islam dan Kemuhammadiyahan, 1990: 3-14) tends to see the subjective and objective reasons. The subjective factor on the establishment was that Kyai Dahlan's personality as a critical, creative ulama who also concerned on every problems faced by Muslim while objective one was derived from his milieu condition, either intern (the condition of Muslim who did not do the pure Islam lesson stained by bid'ah, takhayul, and khurafat), or extern (the political policy of Dutch colonial to Muslim, western education and Christianization carried out by Missi - Zending). This thought was affirmed by Suratno (2009) that through Muhammadiyah, modernism was started by the establishment of Islamic education that integrated general knowledge and Islamic lessons. Kyai Dahlan believed that education can make cultural transformation possible, i.e. the cultural transformation of feudal culture to a modern one. Later on, Kyai Dahlan's progressive idea on traditionalism was conducted through tabligh that at that time was a spectacular event. Suratno (2009: vii) asserts that the tabligh by Kyai Dahlan had opposed the existing mainstream of the common tabligh. By holding reformation motives and the spirit of improvement, tabligh was carried out by visiting students. Though at that time visiting students it was thought as a wrong social act, Kyai Dahlan felt no disgrace. He did so because he wanted to demythologize the position of ulama that could not be reached by common people as has been explained in the above table. 


\section{Notion of Reformation of Islamic Education}

The actualization of Kyai Dahlan's notion was stated on the early program of Muhammadiyah, namely to purify Islam from the strayed lessons (bid'ah, takhayul and khurafat), improving Islamic education and improving the social condition of Muslim (Jainuri in Syamsuddin, 1990: 41). Prof Dr. H. Mukti Ali, as cited by Shabir (in Syamsuddin, 1990:20) classifies programs conducted by Muhammadiyah based on the basic notion from Kyai Dahlan, into four, namely: 1) purify Islam from the influences and habits of non Islam 2) reformulate doctrine of Islam based on modern mind 3) reformation of Islam lesson and education, and 4) strengthen Islam to face influence and threat from non Islam. By analyzing the first programs form Muhammadiyah, intentionally or not, it can be seen that they was influenced by the notion from Syaikh Muhammad Abduh which Gibb (1993: 58) summarizes as follows:

".. (1) purification of Islam from the influence of the strayed lessons and acts [bid'ah and khurafat]; (2) reformation of higher education in Islam; (3) reformulation on Islamic lesson in line with modern mind; (4) defense of Islam towards the influence of Europe and the threat from Christian".

It seems that all programs mentioned above had presumably been formularized by Kyai Dahlan and became his and his successor's obsession until now. Though his formulation on the reformation programs strived by Muhammadiyah was still scattered, as he had not inherited them in a book, his thoughts can be attained from his scattered speech and letters. Considering the socio history as requirement or sine quanon prompted the establishment of Muhammadiyah, it can be seen that the backwardness, deterioration, and the weaknesses of Indonesian Muslim needs solutive programs as has been stated above. For instance, the religious atmosphere of Muslim that was still strayed by the influence and custom from non Islam should be purified with holding the motto: "back to the pure Islam, Al Quran and as sunah".

Traditional Islamic education institution known as pondok pesantren only focused on religion knowledge, where the knowledge had never been transformed into general knowledge; therefore pondok produced alumni opposed to those who learned from Dutch schools. The alumni of pesantren only knew Islamic knowledge and the vice versa, the school alumni only knew general knowledge (Arifin, 1990: 61). This kind of condition was what Dahlan wanted to improve by combining the system of pesantren and the system of western school. In this regard, Dahlan confessed the western education leading in terms of general knowledge and the practical needs pertaining to work field as of those needed in government and private companies. On the other hand, Dahlan also viewed that there was some flaws within western education i.e. in terms of secularity as the effect of lack of teaching on religion. Therefore, it can be understood that 
Moedjanto (1992: 32) concludes that the way Muhammadiyah works followed the acts of Missi and Zending, namely: building schools, hospitals (named by PKO, standing for Pertolongan Kesengsaraan Omoem or General Misery Aid, that was renamed as PKU, standing for Pembina Kesejahteraan Ummat or People Prosperity Supervisor), orphanage and HW boy scout (Hizbul Wathan). The act of Missi and Zending as to carried out Christianization has ignited Dahlan's awareness to defend Islam from their influence and threat, by taking over their system and method.

The reformation plan on Islamic education offered by Kyai Dahlan comprised two aspects: vision and technical thing. In terms of vision, he wanted to build a Muslim who had a good act, understood his religion, had a broad vision and knowledge as well as comprehend general knowledge and was able and ready to struggle for his people (Shabir in Syamsuddin, 1990: 22; Fajar in Nasir and Kunio, 1994: 22) In general, Kyai Dahlan's aim was to build a virtuous but intellect man that may include a cleric who has a good academic or an academician who has a deep understanding on religion (Arifin, 1990: 1990: 63).

The term of technical aspect here refers to the ways in conducting education. R. Sosrosoegondo, second secretary of Budi Utomo who was also Kyai Dahlan's friend asserted that the way Kyai Dahlan organized the educational institution followed the two ways of thinking. First, the improvement of how to learn in pesantren by using facility such as those in private school and by teaching general knowledge like those taught in guvernement schools (state-owned schools). Second, taking religious education into state-owned schools (Arifin, 1990: 64).

Educational institution Dahlan and Muhammadiyah first tried to build was Perguruan al Qismul Arqa in 1918. In 1920, the secondary school was changed into Pondok Muhammadiyah. Pondok Muhammadiyah taught, proportionally, Islamic lessons and general knowledge, trained physics, as well as skills. The students should live in dormitory as well. Mohammad Jasman (in Nasri and Kunio, 1994: 73) says that Pondok Muhammadiyah was not a pesantren and fundamentally different from educational system of pesantren. Later, Pondok Muhammadiyah was changed into Kweekschool Muhammadiyah in 1924 which was divided into Kweekschool Muhammadiyah Putri (which ias now known as Madrasah Muallimat Muhammadiyah) and Kweekschool Muhammadiyah Putra (which is now known as Madrasah Muallimin Muhammadiyah). Now, Pondok Muhammadiyah was tried to be reawakened by Universitas Muhammadiyah Surakarta (UMS) by using the name of Pondok Hajjah Nuriyah Shabran which Mohammad Djasman viewed as the most appropriate way to build the cadres of Muhammadiyah.

Meanwhile, educational institution in the second category in Kyai Dahlan's experiment was Sekolah Rakyat or Sekolah Dasar conducted in Kampung Kauman since 1911. The school was an elementary educational institution which developed Islamic education with the implementation of western educational standard. In 1923, there were a few units of similar schools such as in Kauman, 
Bausasran, Karangkajen, Kotagede. Furthermore, it was spread to other cities afterwards (Arifin, 1990: 64). Those kinds of schools were then developed into a certain kind of schools such as 3 year village school (Vervolkschool), 6 year sekolah rakyat (Standaarschool) and Hollands Inlandsche School (HIS Met Den Qur'an to compete HIS Met Den Bijbel which was built by Zending.

The reformation on Islamic education offered by Kyai Dahlan, was not only spread through educational institutions conducted by Muhammadiyah, but also through certain forums such as pengajian either for older people, youngster, or female. A. R. Fachruddin (in Nashir, 1990: 8) lists some of the pengajian, namely Ikhwanul Muslimin, Toharotul Qulub, Fathul Asror, Miftahus Sa'adah, Sumarah Ngalah, Sidik Amnah Tabigh Fathonah, and so on. Among the ayats motivated Kyai Dahlan to do the reformation as what was often conveyed in the abovementioned pengajians were Ali Imran ayah 104, al Ashr ayah 1-3, and al Ma'un ayah 1-7.

"Let there arise out of you a group of people inviting to all that is good (Islâm), enjoining Al-Ma'rûf (i.e. Islâmic Monotheism and all that Islâm orders one to do) and forbidding Al-Munkar (polytheism and disbelief and all that Islâm has forbidden). And it is they who were the successful.

You [true believers in Islâmic Monotheism, and real followers of Prophet Muhammad SAw and his Sunnah (legal ways, etc.)] are the best of peoples ever raised up for mankind; you enjoin Al-Ma'rûf (i.e. Islâmic Monotheism and all that Islâm has ordained) and forbid Al-Munkar (polytheism, disbelief and all that Islâm has forbidden), and you believe in Allâh ${ }^{\mathrm{I}}$. And had the people of the Scripture (Jews and Christians) believed, it would have been better for them; among them are some who have faith, but most of them are Al-Fâsiqûn (disobedient to Allâh - and rebellious against Allâh's Command)" (Ali Imran" 104 and 110).

"By Al-Asr (the time). Verily! Man is in loss, Except those who believe (in Islâmic Monotheism) and do righteous good deeds, and recommend one another to the truth (i.e. order one another to perform all kinds of good deeds (Al-Ma'rûf ÇáãÚÑæÝ)which Allâh has ordained, and abstain from all kinds of sins and evil deeds (Al-Munkar ÇáãäßÑ)which Allâh has forbidden), and recommend one another to patience (for the sufferings, harms, and injuries which one may encounter in Allâh's Cause during preaching His religion of Islâmic Monotheism or Jihâd, etc.). (Al Ashr: 1-3).

"Have you seen him who denies the Recompense?

That is he who repulses the orphan (harshly),[]

And urges not the feeding of AlMiskîn (the poor),[]

So woe unto those performers of Salât (prayers) (hypocrites),

Who delay their Salât (prayer) from their stated fixed times,

Those who do good deeds only to be seen (of men),

And refuse $\mathrm{Al}$-Mâ'ûn (small kindnesses e.g. salt, sugar, water, etc.). " (Al Ma'un: 1-7) 
What was special from Kyai Dahlan as the expert of tafsir of Al Qur'an was that, although he had never left a full version of kitab tafsir, his rationalization and actualization method was developed as well. Rationalization method required that Al Quran should be read, understood and comprehended. The actualization method requires the implementation of al Quran within the real world. 'Less talk and do more' was the motto led Kyai Dahlan (see Syaifullah in Suara Muhammadiyah, no. 12/79/1994: 30-31; Bashori in Tim al-Islam dan Kemuhammadiyahan, 1990: 31-33).

\section{Views on the Connection of Religion and Mind}

Different from Sayid Ahmad Khan who leaved many of his thought in written form, K. H. Ahmad Dahlan did not. His view on the connection between religion and mind can be known from his message published by HB (HoofdBestuur, now Pimpinan Pusat / PP or Head Quarter) Muhammadiyah Majlis Taman Pustaka issued in 1923. His message entitled "Kesatuan Hidup Manusia" or "The Unity of Man's Life" reflected few of his notions as follows:

1. Man needs and should have faith

2. At first, the faith will look as if it is shiny, nevertheless it will be gloomier by the time. But, it is not the faith that looks gloomy, it is the believer.

3. Man should follow an established rule and requirement that is in line with a pure mind, do no ever make your own decision.

4. Men are obliged to find knowledge, do not ever feel enough with the knowledge owned, or even reject other's knowledge.

5. Man need and should apply and implement his main knowledge, do not let the knowledge to be only just knowledge (Mulkhan, 1990: 226).

Abdul Munir Mulkhan (1990: 13-14) has summarized the above Kyai Dahlan's message as follows:

1. The highest knowledge is the knowledge about the comprehensive life. The knowledge will only be achieved by critical and open mind, the use of logical mind and istiqomah or consistency that is based on pure heat as to get the truth of mind.

2. Mind is the basic need of man.

3. Logic (ilmu mantiq) is the highest education to the people's mind and it can be achieved through the obedience towards God's way.

4. The cooperation is a comprehensive principle that can be carried on by using Al Quran method.

5. The principle of comprehensive life is the absolute requirement to improve humans' life.

6. Loss, fail and mistake of higher clerics are resulted from their ignorance on people's prosperity and life.

7. The first step to get the comprehensive life is critical mind towards tradition.

8. Broken and ruined life is caused by mistake. 
9. Goodness and smartness here are the readiness on comprehending good and wise thought.

10. Strong people were those who were ready to confess the truth and the goodness of the others.

11. Understanding is easier than the implementation. Therefore, people who have those understanding will be more much in number than those who implement what they understand.

Through the above analysis, it can be seen that Kyai Dahlan placed mind and logics in the highest position as the basis on everything that will be very hard to achieved if feudalism was still alive in society. The importance of this mind and logics was not only related to the profane, but also to the understanding towards belief. Furthermore, the mind and logics were placed as the method to achieve the perfect highest knowledge.

Presumably, this is somehow in line with the notion from Albert Einstein, the German scientist who proposed the theory of relativity and who invented atom bomb who says:"Science without Religion Is Lame, Religion without Science Is Blind". Furthermore, Mulkhan (1990, 8-9) also summarizes Kyai Dahlan's thought and view pertaining to belief as follows:

In the terms of aqidah, Kyai Dahlan follows the views in line with the view and thought from salaf.

1. According to Kyai Dahlan, having a belief is doing some acts, i.e. bringing the soul and life only for Allah SWT, which is proved by acts and deeds such as : sacrifying wealth and life, as well as work only for Allah's will

2. The basic Islamic law is al Qur'an and sunnah. Following them, if the law was not explicitly stated within the source of law, was logically reasoning, ijma' and qiyas.

3. There are five ways to comprehend al Qur'an, namely: a. understanding the translation, b. understanding the aims within (tafsir), c. self questioning, d. leaving what Islam forbid and doing what it requires, e. not to find another ayahs before doing ayahs that has been understood.

4. Kyai Dahlan asserts that acts is the actualization of translating al qur'an and organization is the media for the acts.

5. Ghirah (spirit) and intention to make some move is the basis for moral and sincerity in action.

6. Understanding assorted kinds of knowledge spread in society is the key for life improvement and for the Muslim improvement. Regarding this, Kyai Dahlan has ever said "be an engineer, teacher, maser, and back, strive with Muhammadiyah"

7. Caderization is done through direct interaction such as through HW boy scout, Quran study group for youngster - teenagers, and so on.

8. The strategy to deal with social change as the effect of modernization, is by referring to al - Quran, eliminating fanatics and taqlid. The strategy is done by igniting soul and spirit of ijtihad through logical rational though and social 
reality study.

9. The objek of dakwah of Muhammadiyah spread to people in lower social class, the poor, the rich, and intellectuals.

The focus of Kyai Dahlan's thought that emphasized the role of logics and mind as well as the needs of reformation in Islamic education showed a deep influence from an Egyptian reformist, Muhammad Abduh. It is reasonable since Kyai Dahlan quite intensively followed Abduh's thought cited in journal of $\mathrm{Al}$ Manar magazine organized by Rasyid Ridha, Abduh's student. Regarding his, there was a story from Noer (1990: 87), which was both affirmed by the leader of Muhammadiyah and Al-Irsyad, as follows:

"one day, Dahlan and Sorkatti sit head to head in a train passing Java without knowing each other. As to kill the time, at that time Dahlan read Tafsir Al Manar written by Abduh and it interested Soorkatti who did not expect that a villager can read that kind of scientific book.

That made them involved in a talk which led them to promise that they would have their attempt to spread Abduh's mind in their own society, i.e. among Arab and Indonesian's society"

\section{The Political View of K. H. Ahmad Dahlan in Eliminating Feudalism}

It is quite hard to know what K. H. Ahmad Dahlan's political view is, especially towards colonialism. However, among those implicit views, it can be ensured that Kyai Dahlan, since the beginning of his reformation, was not interested to much in politics. Social-religious, especially education matter, was more concern of him. He presumably thought that the later was more urgent.

His join with Budi Utomo, said Akira Nagazumi, was aimed at Islamizing the members. Besides, Kyai Dahlan hoped that by having contact with the members of Budi Utomo which was dominated by state-owned teachers and authorities in the government, there would be an open chance for him to spread his notion on religious reformation within schools. His attempt was successful and his notion was well accepted, especially by the members of Budi Utomo who was also santri in Kampung Kauman, Yogyakarta. Several activists from Budi Utomo who really supported his notion were: R. Sosrodoegondo, the second secretary of Budi Utomo who was also the teacher of Kweekschool Yogyakarta, and Mas Radji, his follower (Nagazumi, 1989: 123).

Nevertheles, it should also stated here that Budi Utomo was not a political organization, rather it was more concerned on socio cultural field; therefore, it can be said that there was a similar intention between Budi Utomo and Muhammadiyah that caused a good relationship between them. Furthermore, it should be remembered that the establishment of Muhammadiya was also helped by the members of Budi Utomo who were known to be close to the colonial government (Nagazumi, 1989: 124). 
A. Syafi'i Ma'arif said that since its establishment, Muhammadiyah tended to be careful and flexible in facing political change. This phenomenon made a positive impression to colonial that Muhammadiyah was not too threatening for their existence so that Muhammadiyah was able to avoid an extreme step from colonial towards the organization (Ma'arif, 1987: 66). Furthermore, as noted by M.T Arifin, though it was small in quantity, Muhammadiyah was ever subsidized by colonial, for example in 1915 (Arifin, 1990" 64).

There was no prove that Kyai Dahlan was very loyal to colonial, or became their collaborator though he indeed worked as abdi dalem in Sultan Yogyakarta where it was known known that sultan was under the control of the colonial government. What was true was that Kyai Dahlan viewed that reformation in social-religious field (especially education) was more urgent than reformation in political field that might cause confrontation with colonial. While confrontation was seen as damaging to Islamic society, the work field of Muhammadiyah that was far from political area placed the organization as an alternative for the dakwah of Islam or Islamic missionary, so that the development of Muhammadiah was elegant. Nevertheless, Muhammadiyah did not take politics for granted. Even, the members of muhammadiyah were given a very wide chance to join every political organization they liked and chosed (Pringgodigdo, 1986: 19).

According to Mailrapport's note (1922 in Peacock, 1990: 28), Kyai Dahlan and Muhammadiyah had never been suspected by colonial as he "avoided independence movement tactics, midnight confidential meeting involving dzikir and so forth". Furthermore, Bakker, one of Catholics missionaries who was also one of the strongest foes of Muhammadiyah, praised Kyai Dahlan as a man with a good tolerance to Christians. The official colonial report about Kyai Dahlan (Peacock, 1990: 27) was as follows:

“... as a gentlemen, militant and brilliant who was in the age of 40 , who seems to have Arabic and very orthodocs with a little tolerance .... Personally, $H$. Dahkhlan shows a good impression; some says that he is a man with a strong character and has a will to do, which cannot be seen either in Netherland or in Europe".

\section{The Long Term Influence}

By analyzing the data on the great development of Muhammadiyah (in Mulkan, 1990: 44, for instance), it can be generalized that Muhammadiyah had a quite big role in national building. It can be said that Muhammadiyah had been through three different phases (Dutch colonization, Japan colonization, and the independence phase) without leaving the struggle, helping each other. Muhammadiyah gave their best whenever they had to involve in the struggle to achieve, defend, and maintain the independence. The data toward the development of Muhammadiyah cited from Abdul Munir Mulkhan in the early of 1990s are as follows: 
HISTORIA:

International Journal of History Education, Vol. XI, No. 1 (June 2010)

\begin{tabular}{l|l|l|l|l|l|l|l|l|l}
\hline Effort of & 1912 & 1922 & 1932 & 1942 & 1952 & 1962 & 1972 & 1988 & 1992 \\
\hline Member & 9 & 988 & 7968 & 150,000 & 59,569 & 169,364 & 472,248 & 543,782 & 638,989 \\
Mubaligh & -1 & 232 & - & 3808 & 5399 & 7988 & - & - & - \\
Branch & - & 25 & 463 & 1100 & 1835 & 2740 & 1130 & - & - \\
Local & - & - & 16 & 22 & - & 68 & 94 & 237 & 37 \\
Area & - & - & - & - & - & - & 25 & 25 & 26 \\
Kinder garten/ & - & 7 & 1003 & 1700 & 2004 & 5828 & - & - & 14,461 \\
SMTA & - & 1 & - & 7 & 57 & 75 & - & - & 215 \\
RS/RB & & & & & & & & & \\
\hline
\end{tabular}

While the data on the development of Muhammadiyah within the year of 2000 are as follows: educational institution as of kindergarten were as many as 7,500 units; elementary schoosl as many as 789 units, madrasah ibtidaiyah (MI) similar to elementary school as many as 639 units; sekolah mengengah pertama (SMP) or junior high school as many as 970 units; madrasah tsanawiyah similar to junior high school as many as 488 units; sekolah menengah atas or senior high school as many as 502 units; madrasah aliyah similar to senior high school as many as 171 units; sekolah menengah kejuruan (SMK) or vocational school as many as 248 units; pondok pesantren or Islamic boarding schools as many as 52 units; higher education comprising university, higher institute, academy or polytechnic as many as 11 unit; while the number of members who had had organizational ID card was as many as 1 million (cited from Hamid et al, 2000: 23).

There were also quite a large number of independent heroes and well known national figures who had ever studied in Muhammadiyah or came from Muhammadiyah family. For example, Ir. Soekarno (1901-1970) the proclamator and the first president of the Republic of Indonesia had been involved as an active member within Majelis Pendidikan dan Pengajaran or Educational and Teaching Institution (now Majels Dikdasmen) during his exile in Bengkulu. Soedirman (1916 - 1950), a general and the first army or Tentara Nasional Indonesia's commander, within his youth actively involved as pemuda muhammadiyah coordinator and HW boy scout (see Notosusanto in Abdullah, 1988: 49). Some of Muhammadiyah were also active in PETA (Pembela Tanh Air), such as Kasman Singodimejo and Mulyadi Joyomartono. Furthermore, Jeneral Soeharto (born in 1921), the second president of republic of Indonesia, was also said as one who had ever studied in Muhammadiyah namely in MULO (in the same level of junior high school. He also confessed as one of Muhammadiyah youngster in his speech on the opening ceremony of $43^{\text {rd }}$ muktamar Muhammadiyah in Banda Aceh in June 1995.

Under the colonization of Japan, the head of Muhammadiyah at that time, namely K.H. Mas Mansur (period of 1936-1942), along with Bung Karno, Bung Hata, and Ki Hajar Dewantara who was known as empat serangkai, also contributed in being the leader and led Indonesian muslin who was under the control of Japanese military (Soebagijo I.N., 1982). Similary, Ki Bagus Haikusumo 
(head of HB Muhammadiyah for periode 1942-953) with his capacity as the member of PPKI (Panitia Persiapan Kemerdekaan Indonesia), had given a great role when there was a revision on August 18, 1945 towards the words within Pancasila i.e. the first basic principle. It was Ki Bagus Hadikusumo who suggested the terms of "Ketuhanan Yang Maha Esa" or "Belief in the One and Only God" to replace the formulation within Piagam Jakarta "Ketuhanan dengan kewajiban menjalankan syariat Islam bagi pemeluk - pemeluknya" or "Belief in God with obligation on doing Islamic laws for the believers" (see Anshari, 1986: 58; and Boland, 1985: 39).

Roeslan Abdoelgani (in Tim Pembina al-Islam dan Kemuhamadiyahan, 1990: 44) confessed that Muhammadiyah had a great role and merit in the national historical chain starting from the era of the national awakening, especially in the field of education - pedagogy, the work field concerned by Muhammadiyah. Mitsu Nakamura (in Tim Pembina al-Islam dan Kemuhammadiyahan, 1990: 114) viewed that there was two kinds of contribution given by Muhammadiyah to Indonesian people and nation, namely : 1) its contribution in creating unity in Indonesia. Regarding this, Muhammadiyah had supported the existence of republic of Indonesia as a political entity; and

2) Muhammadiyah has come as a medium to bear and develop people initiation as to gain independency. In regard with this, Muhammadiyah is a dynamic and asset as to motivate society to gain the national development take off state.

As an organization emphasizing the act of education and social belief, the role played by Muhammadiyah must not be limited by membership and organization, instead, the role can be directed as to build the state of mind, especially that one pertaining to knowledge, good deed and Islamic way of life. It has ever been asserted by A. Malik Fajar (in Nasri and Kunio, 199, where he states that if Muhammadiyah is only identified as an organization, it will be limited by structure, mechanism and membership. On the other hand, as the state of mind, the existence of Muhammadiyah will spread to the whole society and will be considered as rahmatan lil 'alamin (bless to whole world).

\section{Conclusion}

In the early of $20 \mathrm{M}$, Muslim, especially Indonesian witnessed the birth of Islamic reformation. The phenomenon was prompted by the state of Muslim community which was shadowed by feudalism indicated by poverty, low intelligence and backwardness; the fact that Islam had ever been far from al qur'an and assunah; the condition of educational tradition which was left behind and out of date; as well as external factor from western which brought a more leading civilization.

In Indonesia, this movement was pioneered by K. H. Ahmad Dahlan (18691923), a khatib of Masjid Sultan Yogyakarta the local mosque, who established 
organization named Muhammadiyah in 1912. In order to carry out reformation in Islam, especially in education, the founder of Muhammadiyah was influenced by the Egyptian reformist, Syaikh Muhammad Abduh (1849 - 1905), through the journal al - Manar he read. The influence of Abduh was reflected in the Muhammadiah's early programs.

K. H. Ahmad Dahlan came from noble class. His childhood was spent in a harmonious family that built his personality characterized by critical and emphatic mind towards the reality of Muslim society around him. K. H. Ahmad Dahlan viewed that reformation towards Islamic education was important. He thought that mind played an important role in religious life. Mind is a reasoning means to comprehend religion appropriately.

Regarding the importance of reformation of Islamic education, his movement was directed to the creation of man of action; accordingly, the educational institution he built was more of elementary and secondary educational institution. Just right after independence, Muhammadiyah began to build higher education.

In organizing Muhammadiyah, K. H. Ahmad Dahlan was more interested in social, religion, and educational field. In fact, his decision was very appropriate, so that Muhammadiyah could exist until these days, even developed and improved within a short time period.

\section{REFERENCES}

Abdoelgani, R. (1990). "Peranan Muhammadiyah dalam Perjuangan Bangsa", dalam Tim Pembina Al - Islam dan Kemuhammadiyahan Universitas Muhammadiyah Malang (UMM). Muhammadiyah Sejarah, Pemikiran, dan Amal Usaha. Malang : Pusat Dokumentasi dan Publikasi Universitas Muhammadiyah Malang (PDPUMM)

Anshari, E. S. (1986). Piagam Jakarta 22 Juni 1945. Jakarta : CV Rajawali.

Arifin, M. T. (1990). Muhammadiyah Potret yang Berubah. Surakarta : Gelanggang Pemikiran Filsafat, Sosial, Budaya dan Kependidikan.

Asrofie, M.Y. 2005. Kyai Haji Ahmad Dahlan Pemikiran dan Kepemimpinannya. Yogyakarta: MPK-SDI PP Muhammadiyah.

Atmosudirdjo, P. (1970). Sejarah Ekonomi Indonesia Dari Segi Sosiologi Sampai akhir Abad XIX. Jakarta: Pradnya Paramita.

Boland, B. J. (1985). "The Struggle of Islam in Modern Indonesia", terjemahan Saafroedin Bahar. Pergumulan Islam di Indonesia. Jakarta : Grafiti Pers.

Bruinessen, M.V. (1992). Tarekat Naqsyabandiyah di Indonesia. Bandung : Mizan.

Fajar, A. M. (1994). "Mencari Dasar Filosofi Pendidikan Islam: Sebuah Tinjauan Terhadap Pendidikan Kemuhammadiyahan dan Al - Islam”, dalam Imron Nasri dan A. Hasan Kunio, (peny.). Di Seputar Percakapan Pendidikan dalam 
Muhammadiyah. Yogyakarta : Pustaka SM.

Gibb, H. A. R. (1990). "Modern Trends in Islam”, terjemahan Machnun Husein. Aliran - aliran Modern dalam Islam. Jakarta : PT Raja Grafindo Persada.

Herry, S. (2005). Tajdid Muhammadiyah : Dari Ahmad Dahlan Hingga A. Syafii Maarif. Jakarta: Grasindho Khasanah Ilmu.

Hamid, E.S.M. (eds.). (2000). Rekonstruksi Gerakan Muhammadiyah pada Era Multiperadaban. Yogyakarta: UII Press.

Jainuri, A. (1990). "Muhammadiyah Sebagai Gerakan Pembaharuan Islam", dalam M. Din Syamsuddin, (ed.). Muhammadiyah Kini dan Esok. Jakarta : Pustaka Panjimas.

Koentowidjojo, "Dalam Masyarakat Industrial Ulama Bukan Lagi Kategori Sosial, Republika. 21 Oktober 1994, hal. 6.

Ma'arif, A.Sy. (1987). Islam dan Masalah Kenegaraan Studi tentang Percaturan dalam Konstituante. Jakarta : LP3ES.

Moedjanto, G. (1992). Indonesia Abad ke - 20._Jilid I. Yogyakarta : Kanisius.

Mughni, A. S. 1959. Hassan Bandung Pemikir Islam Radikal. Surabaya : Bina Ilmu.

Mulkhan, A.M. (1990). Pemikiran K. H. Ahmad Dahlan dan Muhammadiyah dalam Perspektif Perubahan Sosial. Jakarta : Bumi Aksara.

Nagazumi, A. (1989). Bangkitnya Nasionalisme Indonesia, Budi Utomo 1908 1918. Jakarta : PT Pustaka Utama Grafiti.

Nakamura, M.. (1990). "Dua Kontribusi Muhammadiyah”, dalam Tim Pembina Al - Islam dan Kemuhammadiyahan UMM. Muhammadiyah Sejarah, Pemikiran dan Amal Usaha. Malang : PDPUMM.

Nakamura, M.. (1983). Agama dan Lingkungan Kultural Indonesia Pengaruh Gerakan Muhammadiyah dalam Pemurnian Agama Islam, diindonesiakan oleh Muhadjir M. Darwin. Surakarta : Hapsara.

Nashir, H. (ed.). (1990). Akhlak Pemimpin Muhammadiyah. Yogyakarta : Pimpinan Pusat Badan Pendidikan Kader (PPBPK) Muhammadiyah.

Noer, D. (1990). Gerakan Modern Islam di Indonesia 1900 - 1942. Jakarta : LP3ES.

Notosusanto, N. (1988). "Sudirman : Panglima yang Menepati Janjinya”, dalam Taufik Abdullah. dkk. (ed.). Manusia dalam Kemelut Sejarah. Jakarta : LP3ES.

Peacock, J.L. (1983). Pembaharu dan Pembaharuan Agama. Yogyakarta : Hanindita.

Sedyawati, E. (2007). KeIndonesiaan Dalam Budaya. Jakarta: Wedatama Widya Sastra

Shabir, M. (1990). "Pembaharuan Pendidikan Islam Perbandingan antara Abduh dan Muhammadiyah", dalam M. Din Syamsuddin. (ed.). Muhammadiyah Kini dan Esok. Jakarta : Pustaka Panjimas.

Soebagijo I. N. (1982). K. H. Mas Mansur Pembaharu Islam di Indonesia. Jakarta : Gunung Agung. 
Soeratno, S.C. (2009). Muhammadiyah Sebagai Gerakan Seni dan Budaya Suatu Warisan Intelektual Yang Terlupakan. Yogyakarta: kerjasama LPM Universitas Ahmad Dahlan dengan Lembaga Seni Budaya PWM DIY dan Pustaka Pelajar.

Syaifullah, "MetodologiTafsirK.H.AhmadDahlan",dalamSuaraMuhammadiyah. No. 12/79/1994, 16 - 30 Juni 1994, hal. 30 - 31.

Syuja', Kyai. (2009). Islam Berkemajuan Kisah K.H. Ahmad Dahlan dan Muhammadiyah Masa Awal. Yakarta: Al Wasat (kata pengantar oleh Abdul Mu'ti).

Tamimy, M. D. (1990). "Latar Belakang Berdirinya Muhammadiyah”, dalam Tim Pembina Al - Islam dan Kemuhammadiyahan UMM. Muhammadiyah Sejarah, Pemikiran dan Amal Usaha. Malang : PDPUMM. 